Corrigendum

\title{
Corrigendum to "Ageladine A, a pyrrole-imidazole alkaloid from marine sponges, is a pH sensitive membrane permeable dye" [Biochem. Biophys. Res. Commun. 373 (2008) 419-422]
}

Ulf Bickmeyer $^{\mathrm{a}, *}$, Achim Grube ${ }^{\mathrm{b}}$, Karl-Walter Klings ${ }^{\mathrm{a}}$, Matthias Köck ${ }^{\mathrm{b}}$

${ }^{a}$ Alfred-Wegener-Institut für Polar- und Meeresforschung in der Helmholtz-Gemeinschaft, Biologische Anstalt Helgoland, Kurpromenade 201, D-27498 Helgoland, Germany

${ }^{\mathrm{b}}$ Alfred-Wegener-Institut für Polar- und Meeresforschung in der Helmholtz-Gemeinschaft, Am Handelshafen 12, D-27570 Bremerhaven, Germany

The author regrets an error in line 9 of the first paragraph of the Materials and methods section as well as the first line of the Fig. 2 legend: "Macrobrachium argentinum" should read "Marcobrachium amazonicum".

An error also occurs in the formula for Fig. 1A and this figure appears correctly below:<smiles>Nc1nc2c(-c3cc(Br)c(Br)[nH]3)nccc2[nH]1</smiles> 